\title{
地域協働型道路施設管理を目指した 仕組みづくりと人づくりのあり方に関する研究
}

\author{
岐阜大学大学院 大野 沙知子 ${ }^{* 1}$ \\ 岐阜大学高木 朗義 ${ }^{* 2}$ \\ 岐阜大学倉内 文孝 ${ }^{* 3}$ \\ 岐阜大学出村 嘉史 ${ }^{* 4}$
}

By Sachiko OHNO, Akiyoshi TAKAGI, Fumitaka KURAUCHI and Yoshifumi DEMURA

社会資本を資産と捉えて管理するアセットマネジメントが導入されつつある中で, 安全 で安心な地域を維持していくためには，従来，自治体が担っている公共の領域を見直し， 様々な担い手を活用した道路施設管理体制が必要といえる. 本研究では, 多様な主体が協 働で道路施設管理を担うための仕組みづくりと人づくりに着目し, 地域協働型道路施設管 理のあり方を検討した，具体的には，先進事例の運用実態を明らかにすることで，従来型 の道路施設管理が抱える課題を抽出し, 仕組みづくりの方向性として, 「自治体間の連 携」，「民間活力の活用」および「住民参加」を示した。また，仕組みづくりから見える 人づくりの課題を抽出し，その方向性として「専門家の育成」，「住民の主体的な活動の 創出」を示し，人づくりを仕組みづくりに結びつけるために「中間支援組織の活用」が重 要であることを示した。ささらに，主体間の関係および各主体の果たすべき役割を整理する ことで, 地域協働型道路施設管理のあり方を考察した.

【キーワード】地域協働，道路施設管理，人材育成，アセットマネジメント

\section{1. はじめに}

わが国の社会資本整備では膨大な道路施設の活用 や長寿命化が重要課題であり, 建設から維持管理に 方向転換するとともに，社会資本を資産と捉えて管 理するアセットマネジメントが導入されつつある. 対処療法的な維持管理から, アセットマネジメント に基づく予防保全型管理に移行することをめざし, LCC を考慮した設計・施工方法や総合的なマネジメ ントに寄与する点検システムが構築されている.

しかしながら，わが国では，財源不足や技術者お よび技術力不足が顕著である地方自治体が大多数の
社会資本を抱えており，適切な管理体制が構築でき ない現状にある ${ }^{122)}$. 国と地方の公共事業は年々減少 しており，特に，地方において減少は顕著である. 2030 年までの維持管理・更新費の見通しにおいても, 維持管理費・更新費が増大すると推計される．シナ リオによるが，維持管理費の一部が捻出できない場 合もある ${ }^{3)}$.つまり，限られた予算の中，自治体が 抱える膨大な道路施設に対し，従来のように行政主 導で維持管理を担う体制を継続することは困難であ る、財政制約の中, サービスレベルを縮減させるこ とや道路を撤退させることも考えうるが，自治体が

\footnotetext{
*1 岐阜大学大学院工学研究科博士前期課程社会基盤工学専攻 058-293-2445 p3121007@edu.gifu-u.ac.jp

*2 岐阜大学教授 工学部社会基盤工学科 058-293-2445 a_takagi@gifu-u.ac.jp

*3 岐阜大学准教授 工学部社会基盤工学科 058-293-2443 kurauchi@gifu-u.ac.jp

*4 岐皁大学准教授 工学部社会基盤工学科 058-293-2446 demu@gifu-u.ac.jp
} 
担っている公共の領域を見直し，様々な道路施設管 理の担い手を活用した仕組みづくりや仕組みを運用 するための人づくりを検討することで地域が抱える 課題の解決になりえると考える. 本研究では, 中長 期的な設計や施工方法の導入および点検システムが 構築されつつある道路施設を対象にする．様々な主 体が協働で道路施設管理を担うための仕組みづくり と人づくりに着目し，主体とその役割，および連携 方法を明確化することで，地域を一体的に管理する 地域協働型道路施設管理のあり方を提案する.

なお, 本研究において, 地域協働とは「一定の地 域を前提として，そこに存在する多様な主体が，当 該地域が必要とする公共的サービスの提供を協力し て行う状態」4)とする.

\section{2. 既往研究を踏まえた本研究の位置付け}

\section{(1) 既往研究のレビュー}

\section{a）道路施設管理のあり方に関する研究}

今後の維持管理のあり方として, 国土交通省は, 「アセットマネジメント導入による総合的なマネジ メントシステムの構築」,「ライフサイクルコスト を考慮する設計・施工法の確立」，「構造物の総合 的なマネジメントに寄与する点検システムの構築」，

「新たな管理体制の構築」，「技術開発と専門技術 者の養成」，「支援策と制度の整備」，「情報提供 と住民参加」の提言をまとめている ${ }^{5)}$. 道路施設管理 については, 維持管理の要素技術が蓄積され, 支援 策と制度が整備されてきた中で, これらを展開し運 営していく仕組みづくりとして，「新たな管理体制 の構築」，「技術開発と専門技術者の養成」，「情 報提供と住民参加」の検討が必要といえる. 内閣府 ${ }^{6}$ ) は, 社会資本ストックマネジメントの展望として, 産官学民の新たな関係を構築することが重要である としている。その意図は，官が担ってきた業務を民 間企業, 地域住民, NP0 などの団体に開くことで管理 の持続可能性を担保することであり, 散在している 技術や情報を集約し, 官民学から人, 技術, 手法を 集めたプラットフォームの整備やストックマネジメ ントを推進することにある。つまり，道路施設維持 管理のあり方には, 様々な主体が関わることが求め られ，そのための仕組みづくりと人づくりを検討す る必要があるといえるだろう。

\section{b）仕組みづくりに関する研究}

地方自治体の道路施設維持管理のあり方に焦点を あてた研究として, 大谷 ${ }^{7)}$ は小規模自治体の連携を提 案している. 具体的には，青森県内を 7 つに区分し， 複数自治体の連携構築を定量的に分析している. 連 携することで小規模自治体が単独で管理する場合よ りコスト削減につながることを示している．大堀 ${ }^{8}$ は, 限られた道路維持管理要員が道路サービスを適切に 保持するための解決策を, 行政需要, 個人および組 織の能力，業績に焦点を当て定量的に評価している. そして, 出先機関への人員配置の工夫を中長期と短 期の 2 段階方式で提案している。このように, 自治 体のあり方に言及する研究が蓄積されつつある.

自治体の財源不足や人材不足が顕著であり, 地域 に面的に分散した道路施設を従来じおりに行政が主 導で対応していくことは量的にも質的にも限界があ る. 2010 年 6 月に閣議決定された「新成長戦略〜

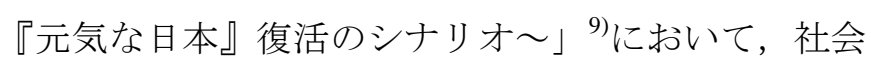
資本ストックについては, 厳しい財政事情の中で, 維持管理のみならず新設も効果的・効率的に進める ため, PFI や PPP の積極的な活用を図るとし, 維持 修繥，更新投資等の戦略的な維持管理を進めるため に民間企業の積極的な介入を目論んでいる，民間の 活力を活用し組織変革を目指す研究として, 赤井 ${ }^{10)}$ は，交通インフラ資産の活用のために，地方有料道 路を取り上げ，地方財務内容の実態を把握したうえ でガバナンスシステムを経済面から評価している.

一方，地域住民自らが，社会基盤整備に携わる事 例を取り上げた研究も見受けられる。佐々木は ${ }^{11)}$, 住民自らが基盤整備の計画・施工を行うセルフビル ドを取り上げ，現況と背景を明らかにしている．津 賀 ${ }^{12)}$ は, 住民参加としてアダプト制度を対象に, 日 本におけるアダプトプログラムの状況把握と他の住 民参加型の環境管理方法との比較からアダプトプロ グラムの有効性・課題について考察している.

\section{c）人づくりに関する研究}

前述のとおり，今後の維持管理には「技術開発と 専門技術者の養成」が求められる。阿部 ${ }^{13)}$ は, 社会 資本ストックを活用する「フローの時代」に移りつ つあること述べ，これからは量ではなく質を重視し た人材が必要であるとし，そのための育成と支援の あり方として NPO 法人橋守支援センターの取り組み 
を紹介している。土木学会編「アセットマネジメン 卜導入への挑戦」では, 道路施設の維持管理のため に，社会資本のアセットマネジメントの重要性を自 治体の経営的側面から理解し，仕組みとして構築・ 浸透させていく人材, 寸なわち, 工学面, 経営面で の知識とともに，維持管理計画を立案・実行できる 能力を身に付けるアセットマネジャーが必要である ことを示している。 また，劣化状態や修緗および補 強対策の判断を行う技術者の育成が必要と示されて いる ${ }^{14)}$ ，そのために，経験豊富な技術者や高度な専 門知識をもった技術者を育成しなければならない.

\section{(2) 本研究の位置付け}

既往研究の整理から, 厳しい制約の中で, 新たな 管理体制の構築が求められていること，管理の担い 手として産官学民が対象であり，行政が一定の関わ りを持ちつつ，新たに民間企業や住民が担うことに よって, 従来の行政のやり方だけでは対応できなく なる領域やサービス提供を検討する必要があること が明らかとなった，人づくりにおいては, 工学面の みならず経営面の知識をもって長期的に維持管理計 画に携わる人材と構造物を適切に判断できる人材が 必要であることを示した。様々な主体が協働する管 理体制において, 主体の役割を明確にし, 適切な連 携方法を提案する必要がある。そのために役割に即 した能力付与が必要である.

本研究では, 全体像を通じて道路施設の維持管理 の仕組みづくりに言及する必要があり, そのための 人づくりが重要であると考える。そこで，仕組みづ くりと人づくりの 2 つの視点から先進的な事例を分 析したうえで, 地域協働型道路施設管理のあり方を 提案することとする.

\section{(3) 研究の構成}

本研究では, まず仕組みづくりに着目し, 地域協 働型道路施設管理に関する先進事例を分析する. ヒ アリングおよび文献調査を通じて管理主体とその役 割を明確にするとともに，管理主体の相互関係につ いても明確にする。 また, 先進事例が解決している 課題を整理することで, 従来の道路施設管理が抱え ている課題を明らかにし, 地域協働型道路施設管理 の仕組みづくりの方向性を示す. 次に, 仕組みづく りから見える人づくりの課題を整理した後, 仕組み づくりに寄与する人づくりについて, 先進事例を分
析する．仕組みづくりと同様に，ヒアリングおよび 文献調查を通じて, 地域協働型道路施設管理の人づ くりの方向性を考察する. 最後に, それまでの考察 を踏まえ, 地域協働型道路施設管理のあり方につい て提案する.

\section{3. 仕組みづくりに関する事例分析}

\section{（1）先進事例を分析するための視点}

まず，事例を分析するにあたり用いた視点を整理 する，先に述べたように，厳しい制約の中で，新た に民間企業や住民が担うことによって，新たな管理 体制の構築が求められている。 そこで, 地域住民や 民間企業を道路施設管理の担い手として位置づける ためには, 各主体の役割を明確にし, 能力に值する 役割を付与する必要がある. 先進事例の整理にあた り「主体」と「役割」を視点として設ける。一方， 既存の枠組みを見直し体制を構築するために主体の 関係性を検討する必要がある。そのために，「連携 方法」を視点として設ける。ささらに，各先進事例を 「実現するためのポイント」や「メリットおよびデ メリット」を視点とし，これらも整理する.

\section{(2) 仕組みづくりの事例}

前節で示した視点を用い. 先進事例のヒアリング 調査および文献調查の結果を表ー 1 に整理した。な お，表－2では，維持管理の流れを「点検」，「調 查・設計」，「施工・補修」と簡略化し，各事例が どの範囲を対象としているかを示した。図ー1〜図 ー6においては，分析に用いた事例がどのような主 体を対象としているか, 主体間でどのような関係が 築かれるかを描いている。主体間の関係性を矢印に して示し, 事例の特徴を補足的として加えた。なお 主体においては, 簡略化のため自治体から県と市町 村を取り出し, 民間企業から設計業者と施工業者を 取り出した. 分析した先進事例を次に示す.

\section{a）権限移譲}

権限移譲とは，地方自治法第 11 章第 4 節において 定められている事務処理特例制度 ${ }^{15)}$ にって, 地方 公共団体である市町村が事務処理業務等を担当する ことができる制度である，この制度は，住民に身近 な行政はできる限り地方自治体に委祆ることに主眼 を置いている，事務手続き等において，様々な自治 体で導入されている，道路施設管理においては，現 
表ー1 仕組みづくりに関する先進事例の調査結果

\begin{tabular}{|c|c|c|c|c|c|}
\hline 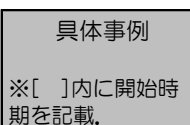 & 関係主体 & 主体の役割 & 連携方法 & $\begin{array}{c}\text { メリット/デメリット } \\
\text { ※○はメリット、メはデメリット }\end{array}$ & 実現のためのポイント \\
\hline \multirow[b]{2}{*}{$\begin{array}{c}\text { 権限移譲 } \\
\text { (広島県-三次市) } \\
\text { [平成19年 }]\end{array}$} & 広島県 & $\begin{array}{l}\text { 管理道路の権限を市 } \\
\text { に移譲する. }\end{array}$ & \multirow{2}{*}{$\begin{array}{l}\text { ○対象路線等, 話合いのうえで, } \\
\text { 道路法17条2項の適用により, 県 } \\
\text { 管理道路を市に権限を含め移譲す } \\
\text { る. } \\
\text { ○管理水準においては県道の基準 } \\
\text { が適庶される. } \\
\text { ○県道管理分の地方交付金を国か } \\
\text { ら直接市が受ける. } \\
\text { ○現在は市内完結の道路が対象で } \\
\text { ある. }\end{array}$} & \multirow{2}{*}{$\begin{array}{l}\text { O既存の市道と一体で管理でき } \\
\text { る. } \\
\text { O住民に身近な行政が業務を担う } \\
\text { ことで迅速に対応できるなど, 住 } \\
\text { 民ササビスの向上につがる } \\
\text { ○県道の管理水準に合わせる必要 } \\
\text { かある. }\end{array}$} & \multirow{2}{*}{ 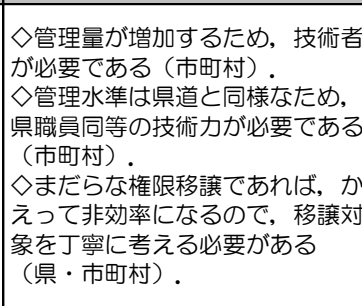 } \\
\hline & 三次市 & $\begin{array}{l}\text { 県が担っていた業務 } \\
\text { と責任を受け, 県管 } \\
\text { 理路線の管理を担 } \\
\text { う. }\end{array}$ & & & \\
\hline \multirow{2}{*}{ 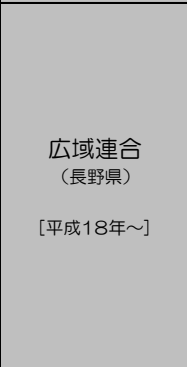 } & \begin{tabular}{|c|} 
上伊那 \\
広域連合
\end{tabular} & $\begin{array}{l}\text { 職員を配置し市町村 } \\
\text { のサポートを行う. }\end{array}$ & \multirow{2}{*}{ 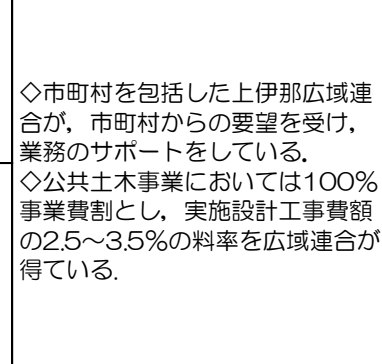 } & \multirow{2}{*}{ 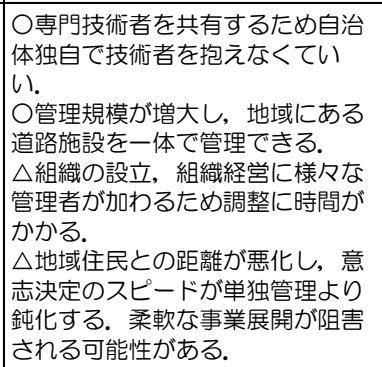 } & \multirow{2}{*}{$\begin{array}{l}\text { ○広域連合を組織化するためには } \\
\text { 自治体間の調整が必要である(自 } \\
\text { 治体). } \\
\text { ○広域管理のための技術力が必要 } \\
\text { である (広域連合). }\end{array}$} \\
\hline & $\begin{array}{c}\text { 2市 } \\
\text { 3町3村 }\end{array}$ & $\begin{array}{l}\text { 通常業務で賄えない } \\
\text { 業務を広域連合に委 } \\
\text { 託する. }\end{array}$ & & & \\
\hline \multirow{2}{*}{$\begin{array}{l}\begin{array}{l}\text { 包括発注 } \\
\text { (青森県) }\end{array} \\
\text { [平成18年 ] }\end{array}$} & 青森県 & $\begin{array}{l}\text { 地域を7つに区分し, } \\
\text { 簡易プロポーザル方 } \\
\text { 式でそれそれん受注 } \\
\text { 者を選定する. }\end{array}$ & \multirow{2}{*}{ 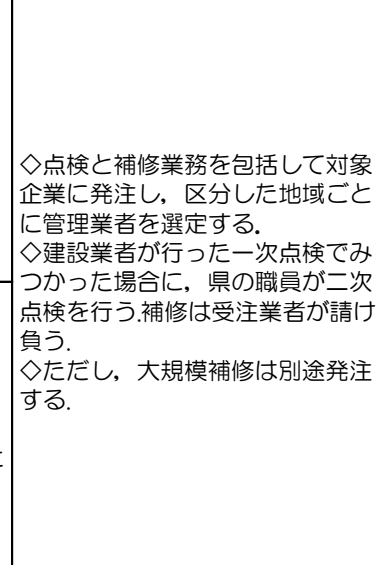 } & \multirow{2}{*}{ 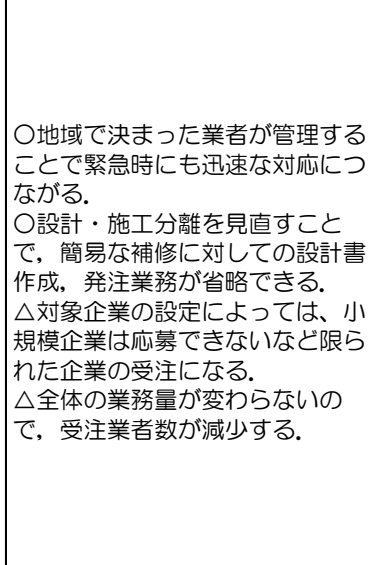 } & \multirow{2}{*}{ 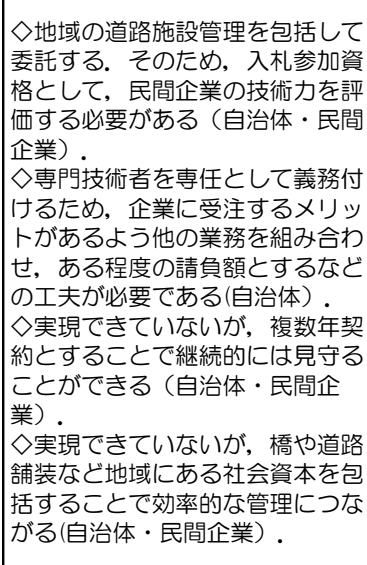 } \\
\hline & 民間企業 & 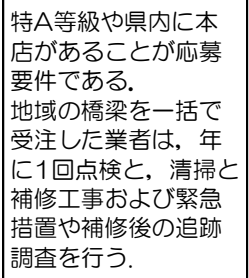 & & & \\
\hline \multirow{2}{*}{$\begin{array}{l}\text { 性能規定型発注 } \\
\text { (米国 } \\
\text { バージニア州) } \\
\text { [平成8年 ] }\end{array}$} & 州交通局 & \begin{tabular}{|l|} 
管理水準を規定し発 \\
注する. \\
年1回水準に基づき評 \\
価をする.
\end{tabular} & \multirow{2}{*}{ 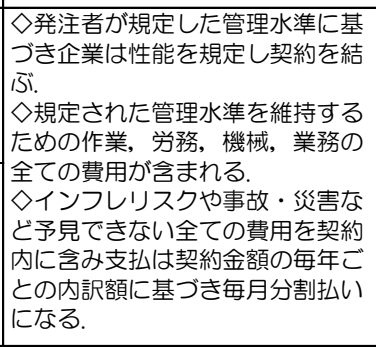 } & \multirow{2}{*}{ 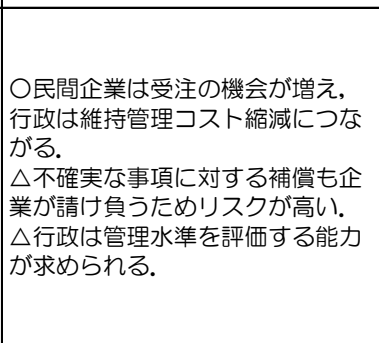 } & \multirow{2}{*}{ 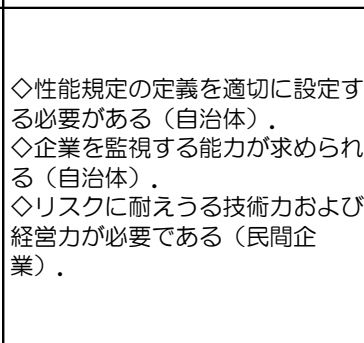 } \\
\hline & 民間企業 & $\begin{array}{l}\text { 性能規定に基づき, } \\
\text { 作業量・作業時期·・ } \\
\text { 施工管理など責任 } \\
\text { を担い実施する. }\end{array}$ & & & \\
\hline \multirow{3}{*}{$\begin{array}{l}\text { アダプト制度 } \\
\text { (徳島県 } \\
\text { 名西郡神山町) } \\
\text { [平成10年 ] }\end{array}$} & 地域住民 & $\begin{array}{l}\text { 自治体管理のインフ } \\
\text { うを里親として引き } \\
\text { 受け, 契約のうえ管 } \\
\text { 理する. }\end{array}$ & \multirow{3}{*}{$\begin{array}{l}\text { ○自治体が管理すべきインフラを } \\
\text { 地域住民に養子として出し, 契約 } \\
\text { のうえ地域住民が管理する. } \\
\text { ○自治体は道具の貸出やアグブト } \\
\text { サインの設置, 自主的な活動促進 } \\
\text { 支援, 参加数の拡大業務を担う. }\end{array}$} & \multirow{3}{*}{ 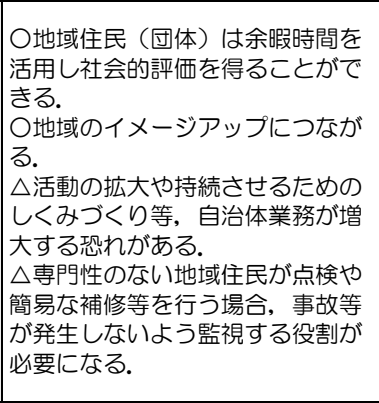 } & \multirow{3}{*}{$\begin{array}{l}\text { ○地域住民の自主的な活動を支援 } \\
\text { する仕組みが必要である（自治 } \\
\text { 体・NOO）. } \\
\text { ○地域住民の参加者を促すために } \\
\text { 地域リーダーが必要である（地域 } \\
\text { 住民）. }\end{array}$} \\
\hline & NPO & $\begin{array}{l}\text { 地域住民と自治体を } \\
\text { NPOが价してお } \\
\text { り, 主に活動支援業 } \\
\text { 務を行っている. } \\
\end{array}$ & & & \\
\hline & 自治体 & $\begin{array}{l}\text { インフラ管理を地域 } \\
\text { 住民に委ね, 備品の } \\
\text { 貸出也動機を保つた } \\
\text { めに支援する. } \\
\end{array}$ & & & \\
\hline $\begin{array}{l}\text { 道普請 } \\
\text { (長野県 } \\
\text { 柿野沢地区) } \\
\text { [戦前 ] }\end{array}$ & 地域住民 & 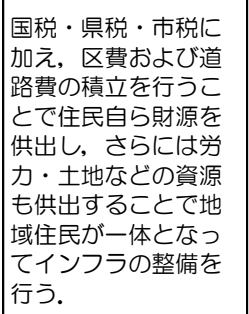 & $\begin{array}{l}\diamond \text { 生活の質向上を地域の共通の目 } \\
\text { 的とし, 区, 常会, 個人といった } \\
\text { 単位で資金, 労力, 資源を出し合 } \\
\text { い, 道路を整備をする. }\end{array}$ & 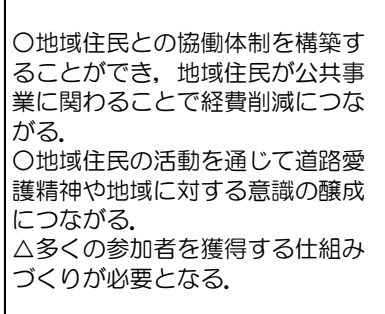 & $\begin{array}{l}\text { ○地域住民の参加者を促すために } \\
\text { 地域リーダーが必要である（地域 } \\
\text { 住民）. } \\
\text { ○個人の生活スタイルや意識に応 } \\
\text { じた参加プログラムの設定が必要 } \\
\text { である (地域住民). }\end{array}$ \\
\hline
\end{tabular}


時点では，広島県三次市，岡山県新見市，岩手県八 幡平市の 3 自治体において取り組まれている。その 仕組みは，指定市以外の市が都道府県に協議し，そ の同意を得れば，都道府県に代わり，補助国道，都 道府県道の管理を行うことができるとされる，具体 的には, 道路占用許可や維持修繥のほか, 道路改良 や災害復旧等も含む, 道路法に基づく管理権限の全 てが移謹される，移蚊を受けた道路の延長・面積に 応じた交付金が国より直接市に交付されることにな る. 道路施設の維持管理においては, 県と市の役割 分担が明確になり, 既存の市道と一体となった管理 ができる．また，住民に身近な行政が業務を担うこ とで通報や要望において迅速に対応できる，このこ とから管理者の混在や二重行政回避につながると言 える (図ー1）。移譲路線は市内で完結する路線を 対象としており市町村同士の連携がされていないた め, 地方自治体間の連携が課題としてあげられる.

広島県三次市の例では，市の管理延長は 1.05 倍程 度になっている ${ }^{16)}$. 仮に, 三次市内にある県管理道 路すべてを移譲すると, 1.2 倍程度の管理量になる. そのため, 基礎自治体に県道の管理権限を移譲する のであれば，管理量や管理の質に応じた人材を備え る必要があり, 技術者や技術力が不足している小規 模自治体に対して，それらを支援する体制が必要と なるだろう。

\section{b）広域連合}

地域を一体で捉え，人材を共有する方法として， 広域行政を担う組織である広域連合を設立する方法 がある（図ー2）。広域連合は, 都道府県や市町村 および特別区が設置することができ，広域にわたり 処理することが適当であると認められる業務に関し て必要な連絡調整を図り, 総合的かつ計画的に広域 行政を推進する組織である ${ }^{17)}$. 広域連合は, 直接国 または都道府県から権限移譲を受けることができ 個々の市町村では実施困難でも, 広域的団体であれ ば実施可能な事務を法律, 政令または条例の定める ところにより直接処理することとすることができる.

広域連合の実態を把握するために長野県の上伊那 広域連合を対象にヒアリングを行った。上伊那広域 連合は, 伊那市を中心に 2 市 3 町 3 村で組織化され, 道路, 橋梁, 砂防, 災害復旧事業, 公共下水道事業 などの土木事業のプロセスのうち, 設計, 数量の算
表一 2 各事例が対象とする範囲

\begin{tabular}{|c|c|c|c|c|}
\hline 仕組み & 関係主体 & 点検 & 計画 • 設計 & 施工・補修 \\
\hline 権限移譲 & 自治体 & & & \\
\hline 広域連合 & 自治体 & & & . \\
\hline 包括発注 & $\begin{array}{l}\text { 民間企業 } \\
\text { 自治体 }\end{array}$ & & & \\
\hline $\begin{array}{l}\text { 性能規定型 } \\
\text { 発注 }\end{array}$ & $\begin{array}{l}\text { 民間企業 } \\
\text { 自治体 }\end{array}$ & & & \\
\hline アダプト制度 & $\begin{array}{l}\text { 地域住民 } \\
\text { NPO } \\
\text { 自治体 }\end{array}$ & & & 簡易な清掃のみ \\
\hline 道普請 & 地域住民 & & & \\
\hline
\end{tabular}
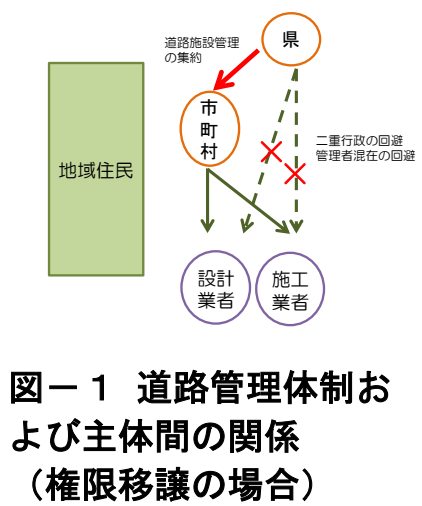

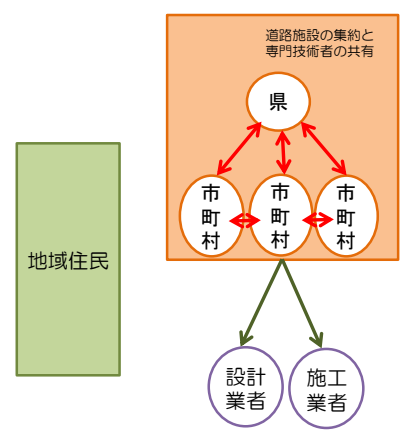

図ー2 道路管理体制
および主体間の関係
（広域連合の場合）
定, 施工計画書策定 - 特記仕様書作成, 積算, 工事 監督など, 市町村のサポートをしている ${ }^{18)}$ 。年度初 めに構成市町村と広域連合とで, 「協議書」を市町 村長と広域連合長とで交わし, 予定される事業とそ れに対応する「負担金」を決定し，4半期ごとに請 求している。年度末に確定事業費により変更協議を 取り交わし「負担金」の過不足の精算をしている.

財源や技術者の量も質も不足している自治体にお いて，自前で技術者の確保や技術力向上のための支 援・制度を活用することなく不十分な部分を補う共 通な組織を保有することで, 円滑に事業を進めるこ とができる．上伊那広域連合では，市町村の補完を 業務としているが, 市町村の業務すべてを担う組織 を構築することで，技術者の確保と活用につながる． その一方で, 自治体が包括された組織であるため地 域住民とつながりが弱くなることが懸念される，意 思決定に時間を有することもあり，単独の管理より 対応が鈍化する可能性がある。ささらには自治体を組 織化することに時間がかかる。 なお，上伊那広域連 
合は，既存の組織を活用しているため広域連合での 業務遂行が実現している.

\section{c) 包括発注}

点検と補修を一体的に発注する包括発注を導入す ることで効率的な管理業務につながる可能性がある

（図一3）。また，発注の際に，地域を包括寸るこ とで発注ロットの拡大につながり, 結果としてコス トダウンが期待できる.

青森県では, 長期的な視点から橋梁の維持管理コ ストを最小化, 平準化を図るために橋梁アセットマ ネジメントシステムを構築している. 日常的な管理 としては，こまめに地元の企業が管理することで効 率的に地域に根差した管理ができると考え, 包括発 注を導入している，具体的には，県を 7 地域に区分 し，各地域の橋梁維持管理を請け負う業者を選定し ている. 業務内容としては, 日常点検, 清掃・維持 工事, 緊急措置に加え, 小規模な補修や床版防水で ある. ${ }^{19220)}$ ，維持管理に関わる業務の請負は，少額で あり，技術者を専任で配置することは困難である。 青森県では, 点検で見つかった大規模補修は別途発 注しているが，小規模工事を契約に含むことで，一 定の額企業が受注できるよう工夫し, 民間企業の専 任技術者を配置している. 地域内の管理を決まった 企業が請け負うことで，緊急時の対応も迅速になる. 受託することで得られる利益は分離発注に比べ大き いものの, 応募の要件として特 A 等級や県内に本店 があるといった受託するための制限が設けられてい る。限られた企業に業務が集中寸る可能性もあるが， 継続的な管理と損傷の早期の対応が求められる維持 管理において地域と業務を一体で発注する方式は有 用である。

\section{d）性能規定型発注}

上述してきた事例は，組織間の連携は実現されて いるものの, 従来どおり行政主導の発注-請負という 体制となっている。これに対し，性能規定型発注は， 民間の技術者と技術力を活用し管理業務を効率的に 行うために導入された発注方式である（図ー4）。

管理者が定義したパフォーマンス基準の達成度に対 して請負者に支払われ，作業量や作業時期等は受注 者の責任で決定される.

アメリカのバージニア州では, VMS. Inc という企業 が 1996 年にバージニア運輸省と契約し, 性能規定で
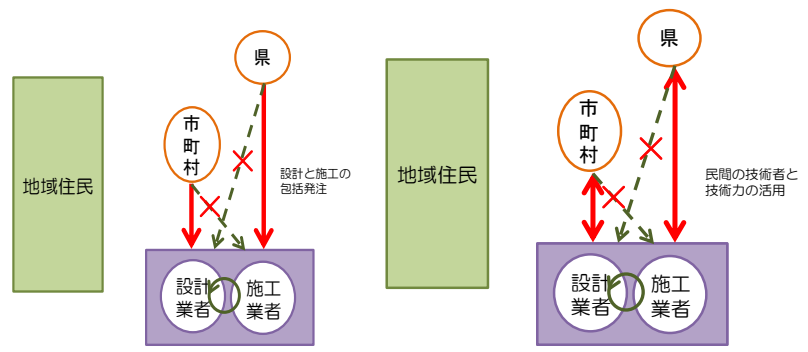

\section{図一3 道路管理体制 および主体間の関係 （包括発注の場合）}

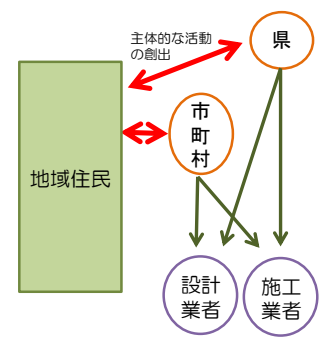

\section{図-5 道路管理体制 および主体間の関係 （アダプト制度の場合）}

\section{図-4 道路管理体制 および主体間の関係 \\ （性能規定型発注の場合）}

の業務を開始している ${ }^{21)}$. 吉田の調査を参考にその 仕組みについて述べると，八イウェイを対象にして， 舗装や橋梁はもちろん, 排水施設や安全施設を含む 道路資産を対象に維持管理から事故対応にいたるま で契約対象としている ${ }^{22)}$ ．事故・災害など予見でき ない全ての費用が含まれていることは注目すべき点 である，すなわち，ある程度の権限を管理者から受 ける企業はリスクを伴うため, 行政の受け典となり 得る経営力が求められる。一方で権限を与える管理 者側も対象路線や管理費について慎重に検討する必 要があり, 監視能力が求められる.

\section{e）アダプト制度}

住民が道路管理の計画策定, 実施, 評価などに参 画できる仕組みを構築することにより，一層の理解 を得ることが可能となり, 地域住民の活動を自治体 が支援することで道路への愛着の醸成にもつながる

（図一 5).

住民参加の事例として，本来は自治体が管理す心゙ きインフラを市民の養子として里子に出し，市民が 管理することを発想の核としているアダプト制度が ある，アメリカで始まった取り組みであるが，日本 では, 1998 年に徳島県名西郡神山町での取り組みが 始まりである。その取り組みは，住民の環境への意 
識を高めるとともに，住民・企業・自治体が協力し て，神山町の道路から散乱ごみを一掃することを目 的として, 道路およびその周辺の紙屑, 空カン, 空 ビン, プラスティック, ビニール等の散乱物の除去 と表示板の清掃, 草取り, 草刚, 花の植栽, 樹木の 剪定等の作業を行っている. 1999 年 10 月に県の正式 な事業として位置づけられ活動を持続させている ${ }^{23)}$. 全国にこの取り組みは広まり，2009 年時点で導入プ ログラム数は 430 件, 活動団体数は 19,000 団体と見 込まれている ${ }^{24)}$. 住民参加の方法は, 行政主導, 住 民主導, 行政主導で住民が協力, 住民主導で行政が 支援など様々な場合があるが，アダプト制度は自ら の意思で主体的に活動をしている個人や団体を公的 活動として自治体が支援する仕組みになっている. ボランティア精神や地域愛着心をもった地域住民を 行政が支援していくことで参加者の意識醸成につな がり参加者がさらに友人や知人に㗢きかけることで 取り組みの拡大を図ることが期待できる.

\section{f）道普請}

道普請とは，社会基盤を地域住民が自ら整備し， 維持していくことを指し示す. 長野県柿野沢地区で は昭和 20 年から 20 年以上にわたり道普請が行われ ていた。地域住民は地縁組織単位で行う「むら仕 事」の一つとして捉えており，「各家にクルマが入 れるように」との地域の共通の目標をもって労力や 資金のみならず土地や資材においても無償提供して いた ${ }^{25)}$.

現在では道普請に類似した取り組みとして余暇時 間を活用した地域活動が活発化している（図－6）. 地域のことは地域で解決する考えが浸透し始める中 で，個人やボランティア団体が地域愛着心をもって 地域で活動することに期待が集まる. 町内会などの 地域自治活動団体に限るのではなく，志をもった人 が集まって活動できるよう工夫することで，自主的 な活動を促進できる. 活動する時間がない人に対し て, 寄付制度等を活用することで, 多くの人を巻き 込む仕組みにつながる。これらの活動を持続させる ためには地域で日常的に活動でき，ある程度の専門 性をもった地域リーダーが必要となる.

\section{（3）先進事例から見た維持管理が抱える課題}

ここでは, 先進事例の分析結果から明らかとなっ た道路施設管理の課題を示す. 先進的な事例が解決 (a) 管理主体の混在

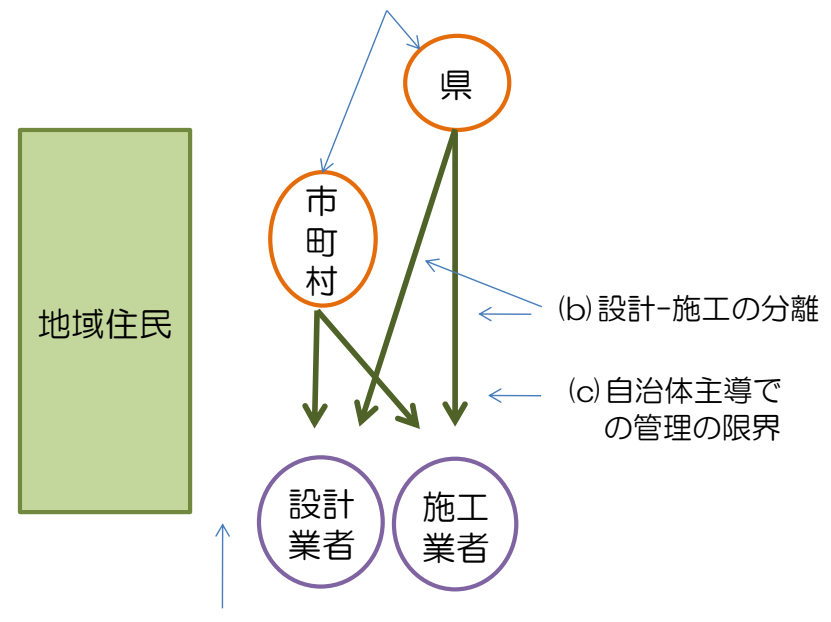

(d) 自主的な住民活動の不足

\section{図ー7 先進事例分析から抽出した 道路施設管理が抱える課題}

しようとしている道路維持管の課題を総括すると， 図ー7のように表すことができる.

\section{a）管理主体の混在}

当然ながら, 都道府県管理の道路施設は都道府県 が，市町村管理道路施設は市町村が管理している. 行政区分に従った管理体制により同様な業務が別々 に発注されているために, 既存の市道と一体となっ た管理ができない，地域住民からの通報に対して速 やかに対応できず自治体間の調整が必要になるなど 非効率となっている点がある。また，管理者ごとに 管理量に応じた人員配置が求められる体制において は，財源不足が顕著であり大多数の道路施設管理を 担う小規模自治体においては負担となる.

\section{b) 点検-補修の分離}

今までは, コスト増加の防止や品質・安全性の確 保および設計の品質チェックのために, 設計と施工 業者を分離することが契約の基本であった。しかし ながら, 点検後に早急な対応が求められる可能性の 高い維持管理において, 点検後の簡易な補修のため に別途発注業務が発生することは非効率である。ま た，規模の小さい維持管理業務において，点検と補 修の分離発注は，逆にコスト増加に繋がる.

\section{c）自治体主導での管理の限界}

増加する維持管理業務に対応するには, 行政が担 っていた業務の一部を民間に開放することが求めら れる。従来の発注-請負体制を見直し，専門技術者が 
不足する行政では対応困難な管理を実施するために, 民間企業のノウハウを活用することが必要である.

\section{d）自主的な住民活動の不足}

道路施設に身近に接しており，実情に詳しい地域 住民が定期的に道路施設を管理することで損傷の早 期発見や道路施設の劣化遅延につながる. 近年, こ れまで行政が主として提供してきた公共サービスに おいて住民団体をはじめ NPO や企業等の多様な主体

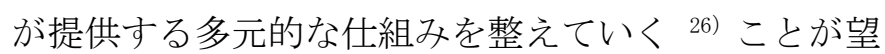
まれる，その担い手として地域住民が主体的に活動 できるような環境を自治体もしくは地域住民自らが 作り出すことが必要である.

\section{（4）仕組みづくりの方向性}

以上の先進事例分析によって, 各事例が解決して いる課題が明らかとなった。ここでは, 先進事例分 析を通して見えてきた地域協働型道路施設管理の方 向性を示寸. 図一 8 に仕組みづくりの事例から見え た道路施設管理が抱える課題と仕組みづくりの方向 性との関係を示す.

\section{a）自治体間の連携}

道路管理が抱えている課題で示したように，道路 管理者が混在していることにより同様な業務が別々 の発注になっている。この点において, 自治体内の 仕組みを見直すことで改善される可能性がある．権 限移譲は，県道を市が管理する仕組みであるが，隣 接した道路が別々の業務として発注されることや, 地域住民からの通報に管理主体が異なるため迅速に 対応できないなどの非効率な点を解消できる，一部 だけを移譲してしまうと自治体の管理量が変わるだ けになってしまうため, ある程度まとめた移譲とす ることが望ましい。道路施設を集約させても，技術 者不足の市町村が多いため, 管理量に応じた人材を 配置する必要がでてくる，小規模自治体においては， 広域連合を組織化し，自治体間の共通業務を集約さ せることで, 自治体独自で専門技術者を保有するこ となく業務を行うことができるといえる.

\section{b）民間活力の活用}

包括発注でみてきたように，ある程度の範囲を一 体として点検と補修業務を包括して発注することで, 発注業務が減少することに加え, 緊急時に迅速に対 応できることが利点としてあげられる，そのことで， 点検後や緊急時の設計書の作成や小規模工事の発注

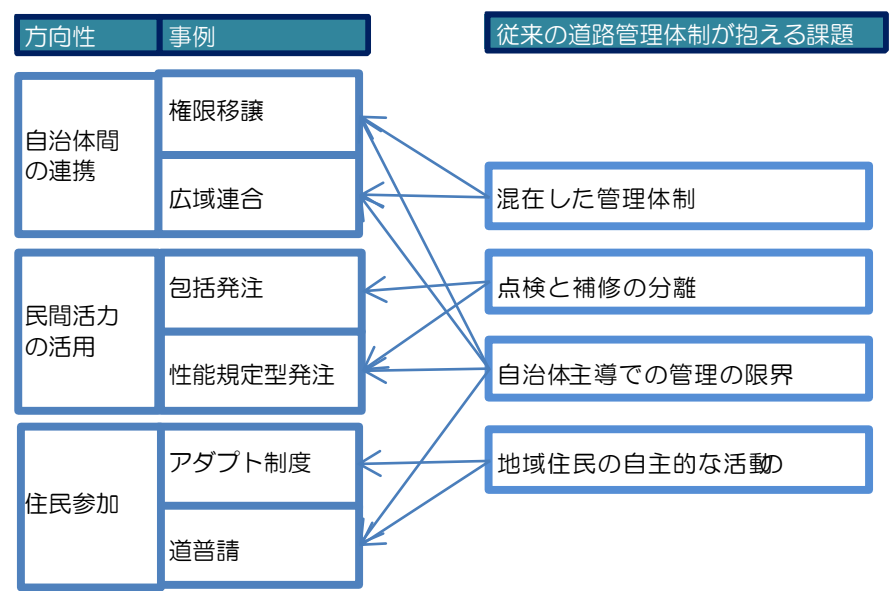

\section{図一8 道路管理が抱える課題と 仕組みづくりの方向性との関係}

が省かれ業務の効率化とコストの削減につながる. また点検と補修をまとめて発注することで，民間企 業においてはスケールメリットが得られ，低コスト で維持管理できる可能性がある。より民間活力を活 用するには，民間企業に点検業務の裁量を委ね，性 能規定の管理に移行することが望ましい，民間企業 の活力を活用するためには，ある程度の発注ロット を確保し，民間企業の利益を確保することが必要で ある。

道路施設管理は，あくまで「公共」の範囲であり 全ての権限を民間企業に委ねることはできないが, 自治体が担う範囲を明確にした上で，各主体のリス クを踏まえ，権限移譲することにより民間企業の技 術力を活用した管理体制につながる。面的に分散す る道路施設を管理する主体として，地域の実情に詳 しく損傷にも早期に対応できる地元の建設業者が, 高度な管理技術を習得することで，疲弊しつつある 地元建設業の活性化につながることが期待できる.

\section{c）住民参加}

住民参加の方法として，アダプト制度で見られる ように志を持って地域活動に貢献している住民を道 路施設管理の担い手として位置付けること，道普請 で見られたように道路施設管理を地域の活動として 創出することなどがあげられる．自主活動を活発化 させるためには，個人の生活や意識の程度に合わせ た活動を設計する必要がある。道普請でみられるよ うに労力のみならず，活動をする人を寄付や物資等 で支援するなどの活動プログラムを設定することで， 地域住民が一体となって活動している人を支援する 
仕組みにつながる．地域で活動している人や団体の 連携を図り活動の拡大を促したり，地域住民に活動 を意識づけるために自治体より地域住民に近い距離 で支援できる NP0 などの中間支援組織を活用するこ とも必要である.

\section{4. 人づくりに関する事例分析}

本章では, 地域協働型道路施設管理の仕組みを運 用するための人づくりの方向性を示す。まず，仕組 みづくりで得られた知見をもとに，人づくりの課題 を抽出する。そして，人づくりにおいて参考となる 先進事例を取り上げ，ヒアリング調査および文献調 査からその事態を明らかにするとともに，地域協働 型道路施設管理における人づくりの方向性を示す.

\section{（1）仕組みづくりから見えてくる人づくりの課題}

仕組みづくりの事例を分析することで，運用面に おいて各主体に必要な知識や技術力が明確になる。 ここでは，主体毎に必要な能力について整理する.

\section{a）自治体に必要な能力}

自治体においては，まず権限移譲や広域連合でみ てきたように自治体間が連携するための能力が必要 である。市町村が県から管理権限を受ける際には市 町村に高度な技術力が必要になり, 広域連合を組織 化する際には広域連合に適切な管理ができる職員を 配置する必要がある. 次に, 民間企業や地域住民に 管理権限を委ねる際には，民間企業を監視する能力 と地域住民を支援する能力が必要になる.

このように, 自治体は工学的な技術力の向上に加 え, 経営面や経済的知識が求められ, それらをもっ て長期的な管理や各主体の支援を行う必要がある.

従来の仕組みであれば，行政に過度の負担を求め ることになるが, 様々な主体との関係性を見直すこ とで, 行政業務の負担は軽減され, 中長期的なマネ ジメントに充てることができる. なお, 前述した仕 組みを活用し, 自治体の役割を明確化かつスリム化 を併せて行うことで, 自治体の負担を軽減させるこ とが望ましい。

\section{b）民間企業に必要な能力}

包括発注を導入するためには，まず対処療法型の 管理に備え点検から施工まで一括で行うことができ る技術を身に付けることが必要である。次に，予防 保全型管理のために何が劣化の原因かを理解し, 現
場で判断する能力を身に付けることが必要である. 民間企業は, 維持管理能力の向上に加え, 自治体が 担っていた責任を移譲できる受け皿が求められる.

\section{c）地域住民に必要な能力}

地域住民を維持管理主体として位置付けるために, 社会基盤の維持管理に目を向けてもらうことが重要 である、そして，地域住民が主体的に活動できる環 境を創出することが必要である。一方で, 地域活動 にあまり積極的ではない住民に対して，日常の活動 に道路施設の点検や側溝の清掃等を意識づける必要 がある。

\section{（2）人づくりの事例}

ここでは，前項で整理した人づくりの課題に資す る先進事例を取り上げる。まず先進事例を分析する ための視点を整理した後に, 各事例についてヒアリ ング調查結果および文献調査結果を示す.

人づくりにおいては，地域協働型の仕組みを運用 するために役割に応じた能力を各主体に付与する必 要がある。そのため,「対象者」と「目指すレベ ル」を視点として設ける。また，人づくりを運用す るために，「実施体制」および「メリット・留意 点」について整理する。なお，人づくりに関して， 事例の収集を試みたが，まだまだ実績が少ないのが 現状である。すべてを網羅できていない可能性もあ るが, 本研究では関連する 4 事例を調査した. 調査 結果を表一 3 に示す。

\section{a）社会基盤メンテナンスエキスパート（ME）}

岐阜大学社会資本アセットマネジメント技術研究 センター (CIAM) ${ }^{27)}$ では，自治体や民間企業の職員 を対象にMEを育成している．自治体と業界双方の 技術力を向上させ，共通の高度な知識を持った総合 技術者を養成することを目指し，自治体および民間 企業の専門家を対象に講義を提供している，資格取 得後も資格者が主体的に活動するMEの会を発足さ せ，県内を 5 つの地域に区分し活動しており，主体 間の情報共有を継続させている. なお, 資格を取得 することで民間企業は，岐阜県の工事において，総 合評価方式の加点対象となるメリットがある.

\section{b）メンテナンスサポーター（MS）}

岐阜県 ${ }^{27}$ は地域住民を対象にMS を育成している. MS は, 地域住民からの公募を受け, 自治体が資格 を付与しており, 普段利用する道路施設の簡易な点 
表ー3 人づくりに関する先進事例の調査結果

\begin{tabular}{|c|c|c|c|c|c|}
\hline \begin{tabular}{|c|} 
具体事例 \\
※[ ]内に間始時 \\
期を記倳。事. \\
\end{tabular} & 実施体制 & 受講刘象者 & 得られる資格 & 目指すしベル & 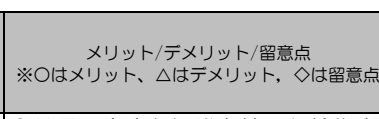 \\
\hline $\begin{array}{c}\text { 社会基盤 } \\
\text { メンテンンス } \\
\text { エキスパー } \\
\text { (ME) } \\
\text { [平成2O年〜] }\end{array}$ & 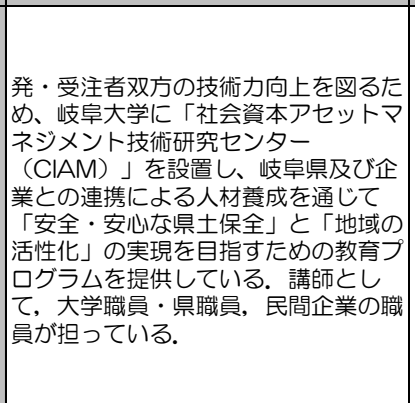 & \begin{tabular}{|l} 
県土木職員・市町村土木職員 \\
県内の建設会社 \\
県内の建設ンルタント \\
県内の調查会社
\end{tabular} & $\begin{array}{l}\text { 社会基盤 } \\
\text { メンテ } \\
\text { エキスパート }\end{array}$ & 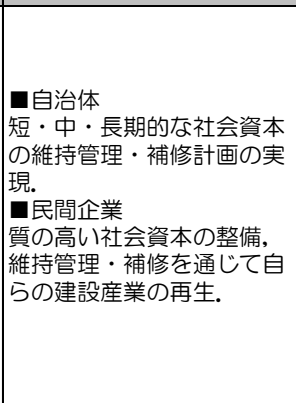 & 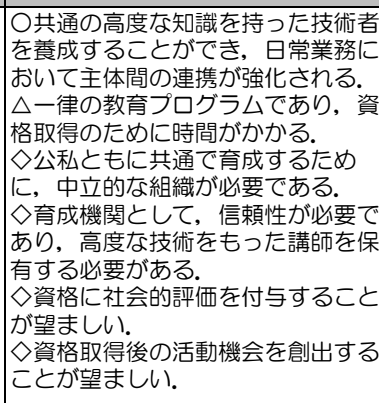 \\
\hline $\mid \begin{array}{c}\text { メンテナンス } \\
\text { サホホーター } \\
\text { (MS) } \\
\text { [平成21年〜] }\end{array}$ & 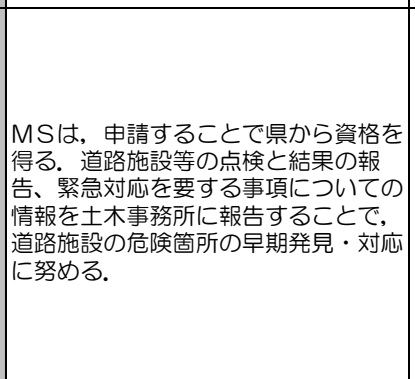 & 地域住民 & $\begin{array}{l}\text { メンテナンス } \\
\text { サポーター }\end{array}$ & $\begin{array}{l}\text { 道路施設等の点検とその結 } \\
\text { 知告、落石や穴ぼこ等 } \\
\text { の緊急対応を要する事項に } \\
\text { ついての情報提供 }\end{array}$ & 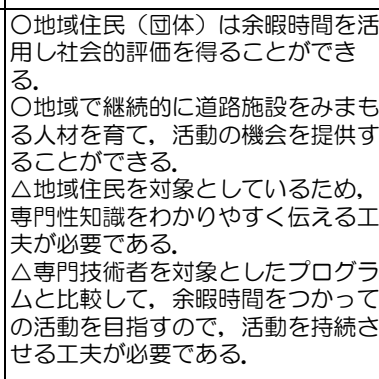 \\
\hline \multirow{3}{*}{$\begin{array}{c}\text { 道守 } \\
\text { [平成19年 ] }\end{array}$} & \multirow{3}{*}{ 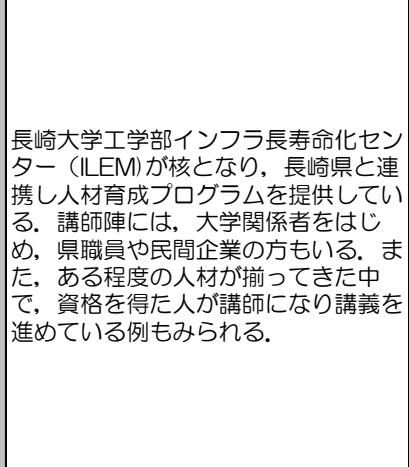 } & \multirow[t]{2}{*}{$\begin{array}{l}\text { 地元企業職員 (OBも念む) } \\
\text { 地元自治体職員 (OBも含む) }\end{array}$} & 特定道守 & $\begin{array}{l}\text { 技術士・ } \\
\text { 博士しベル }\end{array}$ & \multirow{3}{*}{ 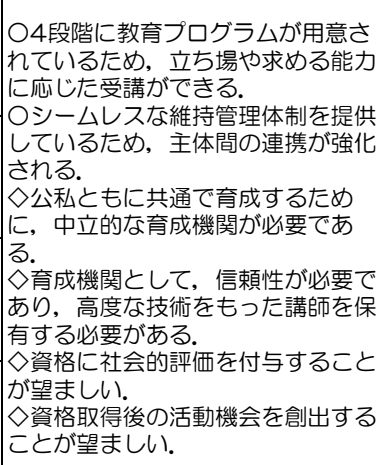 } \\
\hline & & & 道守補 & \begin{tabular}{|l} 
土木施工管理 \\
技士しベル
\end{tabular} & \\
\hline & & 一般市民 & 道守補助員 & 異常に気づく程度 & \\
\hline \multirow{4}{*}{$\begin{array}{c}\text { 橋守 } \\
\text { [平成13年 ] }\end{array}$} & \multirow{4}{*}{ 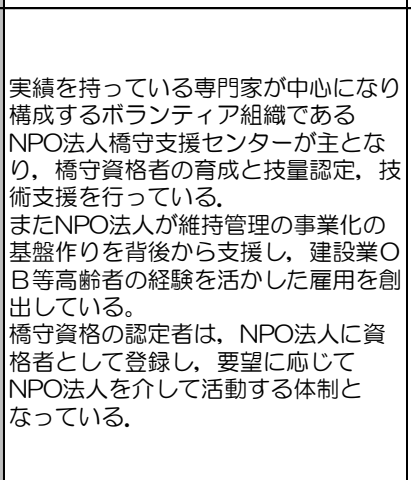 } & \multirow{4}{*}{ 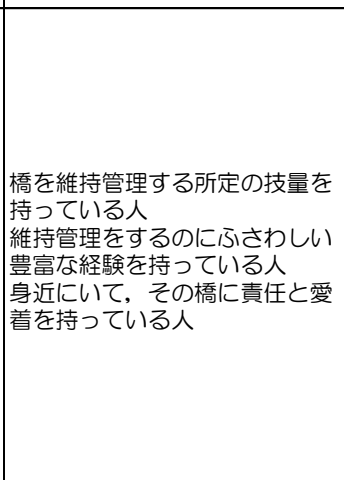 } & 橋守 & $\begin{array}{l}\text { 検查や投資計画に関するマ } \\
\text { ネジメン検查結果に対 } \\
\text { する診断, 評価 } \\
\text { 人材育成の講師, 専門家と } \\
\text { して派遣でさる技量 }\end{array}$ & \multirow{4}{*}{ 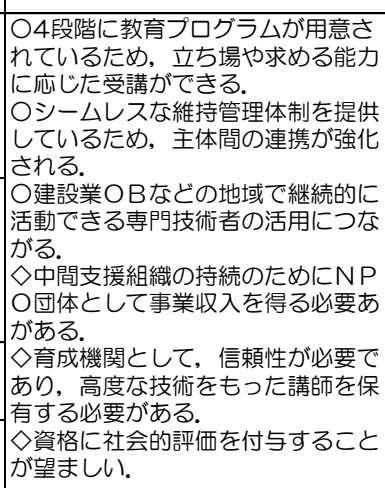 } \\
\hline & & & 特定橋守 & $\begin{array}{l}\text { 専門的診断と専門分野の処 } \\
\text { 方せんの作成 } \\
\text { 補修, リ䛃ニアル等に関 } \\
\text { する設誨工要項の作 } \\
\text { 成, 現地指導 }\end{array}$ & \\
\hline & & & 橋守補 & \begin{tabular}{|l} 
点検作業結果の記録 \\
判定羓務
\end{tabular} & \\
\hline & & & 橋守補助員 & 橋守作業の補助 & \\
\hline
\end{tabular}

検，危険個所等を住民が通報することで損傷の早期 発見・補修することで事故防止・維持費用の低減を 目的としている．地域住民が道路施設を見守ること で長期にわたる状態監視や他住民への地域愛着心の 啓発につながることが期待できる.

なお，先に取り上げたMEとM S が地域内で連携 することで，地域住民を含めた維持管理体制を構築 することができる．MSが身近に道路施設を見るこ
とで地域の実情に応じた情報を即座に得ることがで き，情報を受けMEが対応することで，地域内での 維持管理サイクルを自立させる体制が確立され，道 路施設の劣化に伴う事故等を未然に防ぎ，劣化の遅 延につながることが期待できる.

\section{c) 道守}

長崎大学工学部インフラ長寿命化センター（ I L E M ） ${ }^{28)}$ では，観光ナガサキを支える “道守” 養成 
ユニットを受託し，地域でインフラ管理を行う人材 を育成している.

事業目的として, 点在する観光資源を結ぶインフ ラ管理に貢献するとともに，新たな技術と産業振興 に資する人材育成を支援することとしており，レ心゙ ルに応じたコース別の講義を展開している，コース 別にすることで，点検ができる人からマネジメント できる人等，シームレスな維持管理体制を構築する ことができるよう工夫している.

道守補助員は地域住民からリーダーを育成する仕 組みになっており, 道守補助員が簡単な点検を担い, 専門家の資格者と連動することで，地域内で維持管 理サイクルを自立させる体制の確立につながる.

\section{d）橋守}

N P O 法人橋守支援センター ${ }^{13)}$ は, 地域において 橋の番人としての「橋守」の精神を持った人材と企 業を教育・訓練するとともに，その技量と経験に応 じてその技量の認定と新しい技術を第三者の立場で 確認や評価及び認定し，かつ実務に導入を図るため の標準化をはかることで，低コストで信頼できる人 材と技術を社会基盤である公共構造物の維持管理に 導入する仕組みを作ることを活動の目的としている. 技量認定にとどまらず，人材バンクとして機能し， 必要な人を必要なときに派遣することで資格者の活 動の場も創出している．第三者機関が技術者を保有 し，要望に応じ技術者の紹介と派遣を行うことで維 持管理に関わる主体の補完的機能となっている.

\section{（3）地域協働型道路施設管理の人づくりの方向性}

以上の事例分析を踏まえ, 人づくりの方向性を 「専門家の育成」および「住民の主体的な活動の創 出」の 2 つとして捉え, 調査より得られた知見を総 括する。そして，人づくりを仕組みづくりに結びつ けるために「中間支援組織の活用」が重要であるこ とを示す。

\section{a）専門家の育成}

維持管理においては, 経験と高度な技術力が試さ れ，「知っているつもりだけど（器械の名前は知っ ているけど使ったことがないなど）知らない」こと や「専門以外の知識」を得ることが求められる.

「独学」で学ぶことに限界がある中で, 大学やN P $\mathrm{O}$ 団体が知識や技術を提供し，人材育成に務めるこ とは有用である。先進事例で見てきたように，人づ
くりにおいては，いくつかの方法がある，道守は， 講習のコースが技能別に 4 段階に分類されており， 段階が上がるごとにより専門知識が習得できるよう に設計された仕組みである。一方で，MEにおいて は，専門家育成を目的とした養成コースのみを設定 している，MEを受講することで，自治体と企業間 の情報共有および資格取得後の連携を意図している.

育成方法は様々であるが，民間企業においては， 仕事を受注する際に公的な資格が重要とされるため, 個人の技術力と会社への利益につなげる人づくりを 専門機関が提供する必要がある。自治体おいては, 様々な主体から得られる情報を判断する能力や得ら れた情報を処理し, 中長期的な維持管理マネジメン 卜に役立てる能力を付与する必要がある.

\section{b）住民の主体的な活動の創出}

道守補助員やアダプト制度, 道普請等, 地域を守 るために活動している人は，余暇時間を活動に充て ているだけでなく，地域への愛着をもって自分の時 間を費やしている．MS や道守補助員は，地域住民 に簡易的な点検を依頼することで情報量の増大を意 図しているが，知識を得てもらうことで，質の高い 情報の収集につながっている，地域住民の育成で重 要なことは，社会基盤の維持管理に目を向けてもら うことである。そして，草刚等を日常生活で行うこ とで長寿命化につながるなどの知識を得てもらい. 主体的に活動できる環境を創出することである。地 域愛着心のある地域住民が講義を受け知識を習得す ることで，地域内での道路施設の維持管理の一端を 担うリーダーとして活躍し, 活動が広がりを持つこ とを期待したい。

\section{c）中間支援組織の活用}

人材育成に求められることは，面的に分散した道 路施設を地域で見守るために，地域である程度の PDCA サイクルを自立することができるように担い手 を育成し，担い手の活動に即した能力を付与するこ とであり，育成後の活動を見越した関係性を構築で きるよう工夫することである.

従来の官民二元論では立ちゆかなくなりつつ道路 施設管理に，新たな主体として中間支援組織を加え ることで，誰が人材育成を行い，育成後の活動を誰 が支援するかに応えることができる，人づくりから 地域での活動の過程において中立的な立場である中 
間支援組織を活用することで自治体，民間企業，地 域住民といった立場の異なった主体の連携が円滑に なる。さらには，中間支援組織を仲介し，それぞれ の立場と役割が明確になることで地域での PDCA サイ クルを自立することにつながる.

本研究で取り上げた 3 つの人づくりの事例におい ては，それぞれ対象とする主体や育成方法は異なる ものの, 中間支援組織である大学や NP0 法人が, 個 人に能力を付与するのみならず，活動時に連携でき るよう育成の段階から工夫している。また，資格を 付与した後も中間支援組織としての機能を有し, 各 主体が地域で技術力を還元できるようサポートして いる.

\section{5. 地域協働型道路施設管理のあり方}

前章までに，地域協働型道路施設管理の仕組みづ くりおよび仕組みを運用するための人づくりについ て，課題とその方向性を示した。ここでは，それぞ れの取り組みを俯瞰し, 主体間の関係と役割を明確 にすることで地域協㗢型道路施設管理のあり方を提 案する. 図ー9に地域協働型道路施設管理を示す.

以下に, 図ー9 で示した主体間の関係について示す.

自治体間の関係においては，[権限移譲によより役 割分担を明確にする. 県は市町村が行うにはふさわ しくない業務やリスクの高い道路施設を重点的に管 理する．小規模自治体は［広域連合］を組織化するこ とで技術者を共有する。 そして道路管理施設を包括 的に管理する.

自治体と民間企業の関係においては，民間企業が 実施することでレベルの高い道路施設管理や効率的 にサービスの提供ができるものについて，権限を移 譲する. 発注の際には, 民間企業からの技術提案を 受ける [性能規定型発注）とする。道路施設管理にお いては発注ロットが小さく民間企業の利益につなが らない可能性があるが, 点検と補修を一体とし, 地 域を一体で発注する[包括発注]を導入することで, ある程度の業務が確保可能となる。

地域住民と自治体の関係性においては, 地域の活 動を自治体が地域住民の活動を支援する [アダプト制 度]を活用する．地域住民と自治体が連携するために は [道普請]の取り組みのように地域活動を活発化さ
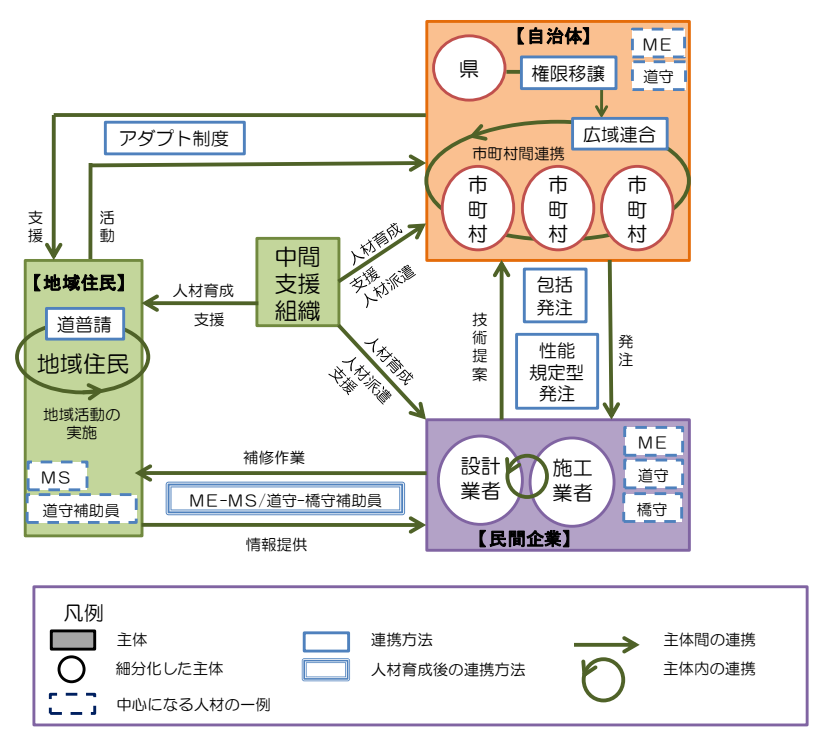

図一 9 地域協働型道路施設管理のあり方

せる必要がある。

自治体や民間企業および地域住民が連携する管理 体制では，中間支援組織が有用となる。中間支援組 織と各主体の関係においては，中間支援組織が人材 育成を担い，それぞれの役割を補う人材を派遣し， 活動が円滑に進むように支援する.

このように自治体や民間企業および地域住民とい った主体が関係を構築し，中間支援組織がそれぞれ の役割を補完する役割を担うことで維持管理サイク ルが自立する体制となる。

以下では，上述した関係を成り立たせるために必 要な各主体の役割について述べる.

\section{（1）自治体の役割}

地域協働型道路管理体制においては，様々な主体 を担い手と位置付けるために, ある程度の管理権限 を各主体に委ねることが求められる。権限を各主体 に移譲することで業務が軽減されるため，長期的な マネジメントに重点を置くことができる，各主体か らの情報をもとに, 長期的な計画を組み立てること が重要な役割になる。 ある程度の権限を様々な主体 に委ねるが, 被害による影響が大きい道路施設等, 他の主体には任すことのできない重要なものを自治 体が重点的に管理する.

また, 従来の体制から役割が変化する中で, 住民 活動のきめ細かな対応や民間企業の監視が自治体の 重要な役割となる. 


\section{（2）民間企業の役割}

通常，民間企業の役割としては，業務を受注する ことで点検や調查および定期的な補修を行うことや， 損傷等が発生した際に迅速な対処ができることであ る.地域協働型の管理においては，道路施設に身近 な地域住民が簡易な点検や簡易な補修を担い，管理 に危険が伴う場合や専門知識が求められる場合にお いては民間企業が担う。また，自治体から管理権限 を受けることで独自の提案により管理水準を保持し， 安心安全な道路施設を提供することが役割となる. 技術提案する際には「対処療法型」の管理に加え, 劣化を遅延させ事故等を未然に防ぐ「予防保全型」 の管理を目指すことが重要である.

\section{（3）地域住民の役割}

町内会や自治連合会といった既存の団体に管理を 依頼することが考えられるが，自主的に活動をして いる団体を道路施設管理の担い手として位置付ける こともできる，道路施設管理を個人の活動のみなら ず地域のイベントとして開催し, 道路維持管理を地 域住民が一体となって行うことで，道路維持管理の 重要性に対する意識が醸成されることが期待できる。 具体的な地域住民の役割としては，「対処療法型」 の管理に寄与する道路施設の不備を早期に発見する 日常の点検である．地域住民がある程度の知識をも つて道路施設を点検することで，有用な情報が得ら れ，機能性を確保するができ，道路施設がもたらす サービスの保持につながる.

\section{（4）中間支援組織の役割}

様々な主体が協働して道路施設管理を実施するた めには，それぞれの役割を補完する中間支援が有用 となる．技術者不足や技術力不足が顕著になってい る中で，信頼のもてる技術者の技術力を地域で確保 することが必要である。専門家バンクとして地域の 人材を一括で保有しニーズに合わせ派遣することや 中間支援組織がそれぞれの役割を補完しつなぎ合わ せながら地域で維持管理サイクルが自立することが 役割となる。

\section{6. おわりに}

本研究では, 安心安全な地域を地域で維持してい くためには，様々な主体がそれぞれの役割をもって 連携する地域協働型道路施設管理が有用であると考
え，その仕組みづくりと人づくりに着目し先進事例 の分析を行った。

仕組みづくりに関する先進事例からは，各主体が 連携することで解決している維持管理の課題を抽出 し，仕組みづくりの方向性を示した。同様に，仕組 みづくりを運用するための人づくりの方向性を，先 進事例を分析することで示した。ささらに，仕組み づくりおよび人づくりの先進事例の考察から地域協 働型道路施設管理のあり方を提案した.

本研究で分析した先進事例を地域の実情に応じて 取捨選択し，組み合わせることで，適切な管理体制 の仕組みを構築できるものと考える．仕組みづくり を地域で運用できるよう人づくりを進めることが今 後の課題であると考える.

謝辞 : 本研究は, 科学研究費補助金（基盤研究 (B), 課題番号：21360243, 研究課題名：社会費用を考慮 した社会資本アセットマネジメントに基づく地域リ スクガバナンス, 研究代表者: 高木朗義）の助成を 受けたものである。ここに記して感謝の意を表する。

\section{【参考文献】}

1）国土交通省：道路橋の予防保全に向けた有識者 会議資料, 2007.

2) 土木学会編：アセットマネジメント導入への挑 戦, 技報堂出版, 2007 .

3）社会資本整備審議会・交通政策審議会計画部会 第 2 回基本問題小委員会:資料 3 社会資本の維持 管理・更新投資,2005

4) 分権型社会に対応した地方行政組織運営の刷新 に関する研究会（総務省）：分権型社会におけ る自治体経営の刷新戦略一新しい公共空間の形 成を目指して一，2005.

5) 国土交通省道路構造物の今後の管理・更新のあ り方に関寸る検討委員会 : 道路構造物の今後の 管理・更新のあり方, 2003.

6) 内閣府総合科学技術会議：今後の社会資本のス トックマネジメント技術の将来展開，2011.

7) 大谷江二, 上田孝行, 森地茂 : 小規模自治体に おける橋梁アセットマネジメントの実施に関す る研究, 土木計画学研究・講演集 vol.39, 2009.

8) 大堀勝正, 森地茂: 道路維持における行政需要 に応じた人員配置の最適化手法, 土木学会論文 集 F vol.66， 2010.

9) 首相官邸：新成長戦略〜「元気な日本」復活の シナリオ〜, 2010. 
10) 赤井伸郎：交通インフラとガバナンスの経済学, 有斐閣，2010.

11）佐々木哲也：セルフビルトによる道づくり，景 観・デザイン研究講演集 No.2，2006.

12) 津賀高幸, 近藤隆二郎：住民参加型の環境管理 方法としてのアダプトプログラムの特徵, 土木 計画学研究・講演集 vol.26, 2002.

13) 阿部充 : 実践土木のアセットマネジメント，日 経 B P 社, 2006.

14）社団法人土木学会 : アセットマネジメント導入 への挑戦，技報堂出版，2005.

15）地方自治法第 11 章第 4 節，1999 年改訂.

16) 三次市ホームページ, http://www.city.miyoshi.hiroshima.jp/kensetsu_m/inf o/news_.jsp

17) 総務省 H P http://www.soumu.go.jp/kouiki/kouiki1.html

18）上伊那広域連合ホームページ, http://www.valley.ne.jp/ kamiina/

19) 青森県県土整備部道路課ホームページ, http://www.hashimori-dankai.jp/
20) 青森県県土整備部道路課 : 青森県橋梁アセットマ ネジメント年次レポート（平成 21 年度），2011

21) VMS.Inc ホームページ, http://www.vmsom.com/company-profile/default.asp

22) 吉田武: 性能規定型メンテナンス契約の現状と課 題, 土木研究所, 2008.

23) 徳島県名西郡神山町ホームページ http://www.town.kamiyama.lg.jp/adopt_fs.html

24）社団法人食品容器美化協会 : アダプトプログラ 么研究会・研究報告書, 2010 .

25）柿野沢区道路委員偏：柿野沢における道普請の 歩み，南信州新聞社出版局，2007

26) 総務省：地方公共団体における行政改革の推進 のための新たな指針，2005

27）社会資本アセットマネジメント技術研究センタ 一：パフレット「社会基盤メンテナンスエキス パート養成ユニット」，2010.

28）長崎大学工学部インフラ長寿命化センター：観 光ナガサキを支える道守養成ユニット成果報告 書, 2011 .

\section{A Study on Governance and Human Resources for Cooperative Road Facilities Management}

By Sachiko OHNO, Akiyoshi TAKAGI, Fumitaka KURAUCHI and Yoshifumi DEMURA

Within today's infrastructure management, Asset Management systems are becoming a mainstream feature. For region where the risk is low, it is necessary to create a "cooperative road facilities management system". This research both examined and suggested what kind of cooperative road facilities management system should be promoted by the regional society.

Concretely, this study defines the operational realities of a previous case. It discusses the problem of the road facilities management as a governance. Furthermore, its realization depends on "the cooperation between municipalities", "the private-sector initiative", and "residents participation" .Also, it discusses the problem of human resources for governance. Its realization depends on " the engineers' promotion ", and " creation of a voluntary activity of the resident " as a human resources. Moreover, it defines that the intermediary is important because the human resources tied to the governance.

As a result, the prospect of the road facilities management is shown by the role of the player and the relation among player. 